\title{
Developmental expression of and effect of betamethasone on the messenger ribonucleic acid levels for peptide growth factors in the baboon fetal adrenal gland
}

\author{
G W Aberdeen, G J Pepe ${ }^{1}$ and E D Albrecht \\ Departments of Obstetrics, Gynecology and Reproductive Sciences and Physiology, Center for Studies in Reproduction, University of Maryland School of \\ Medicine, Baltimore, Maryland 21201, USA \\ ${ }^{1}$ Department of Physiological Sciences, Eastern Virginia Medical School, Norfolk, Virginia 23501, USA \\ (Requests for offprints should be addressed to E D Albrecht, Department of Obstetrics, Gynecology and Reproductive Sciences, University of Maryland School \\ of Medicine, Bressler Research Laboratories 11-019, 655 West Baltimore Street, Baltimore, Maryland 21201, USA)
}

\begin{abstract}
In the present study, we determined whether expression of the messenger ribonucleic acids (mRNAs) for insulin-like growth factor-II (IGF-II), and its principal IGF type-1 receptor and IGF-binding protein-2 (IGFBP-2), as well as basic fibroblast growth factor (bFGF), was developmentally regulated in the baboon fetal adrenal gland. In the second phase of this study, fetal pituitary ACTH was suppressed by the administration of betamethasone to determine the possible effect on the mRNA levels for those factors, i.e. IGF-II and IGFBP-2, shown to be expressed at high levels in the adrenal late in fetal development. Adrenals were obtained from fetuses delivered via Cesarean section on days 60 (early), 100 (mid), and 165 (late) of gestation (term $=184$ days) from untreated baboons and on day 165 from baboons in which betamethasone was administered to the fetus, or to fetus and mother, every other day between days 150 and 164 of gestation. Although the mRNA levels of IGF-II in the fetal adrenal were similar at early, mid and late gestation,
\end{abstract}

IGF type-1 receptor mRNA levels were approximately 2to 3-fold greater $(P<0 \cdot 01)$ at mid than at early or late gestation. In contrast, there was an increase $(P<0 \cdot 001)$ in fetal adrenal IGFBP-2 and bFGF mRNA levels in late gestation. Although fetal adrenal weights and width of the zone of definitive/transitional cells exhibiting immunocytochemical staining for $\Delta^{5}-3 \beta$-hydroxysteroid dehydrogenase $(3 \beta-\mathrm{HSD})$ were markedly suppressed $(P<0 \cdot 01)$ by the administration of betamethasone, IGF-II and IGFBP-2 mRNA expression was not decreased. In summary, very different patterns of mRNA levels for IGF-II, IGF type-1 receptor, IGFBP-2 and bFGF were exhibited in the developing baboon fetal adrenal gland, which may reflect functionally important differences in their respective cellular localization within the cortex, as well as a divergence in the functional development of the fetal, transitional and definitive zones of the baboon fetal adrenal cortex.

Journal of Endocrinology (1999) 163, 123-130

\section{Introduction}

The primate fetal adrenal gland exhibits remarkable growth, and morphologic and functional differentiation in utero (for reviews see Jaffe et al. 1981, Pepe \& Albrecht 1990, Mesiano \& Jaffe 1997), processes essential to the production of cortisol required for fetal organ systems maturation (Ballard \& Ballard 1972) and $\mathrm{C}_{19}$-steroids such as dehydroepiandrosterone (DHA) utilized for placental estrogen biosynthesis (Albrecht \& Pepe 1990). Our understanding of the mechanisms regulating fetal adrenocortical maturation, however, remains incomplete.

Adrenocorticotropin (ACTH) has a major role in fetal adrenal growth, development and steroidogenesis (for reviews see Pepe \& Albrecht 1990, Mesiano \& Jaffe 1997) and it appears that the tropic actions of ACTH are mediated by peptide growth factors produced in the fetal adrenocortical cells (Roos 1974, Voutilainen \& Miller 1987, 1988, Mesiano et al. 1991, 1993). Thus, the fetal adrenal expresses the messenger ribonucleic acids (mRNAs) and proteins for insulin-like growth factor-II (IGF-II) (Han et al. 1987, 1988, 1992, Voutilainen \& Miller 1988) as well as its respective binding proteins and receptors (Ilvesmaki et al. 1993a, Coulter et al. 1996), and basic fibroblast growth factor (bFGF) (Mesiano et al. 1991). Moreover, in vitro studies have shown that IGF-II and bFGF stimulate fetal adrenal growth and their production may depend on ACTH (Crickard et al. 1981, Simonian \& Gill 1981, DiBlasio et al. 1990, Mesiano et al. 1993).

Although in vitro studies have shown that ACTH has the capacity to stimulate the expression of IGF-II 
(Voutilainen \& Miller 1987, Ilvesmaki et al. 1993b, Mesiano et al. 1993) and bFGF (Mesiano et al. 1991) by human fetal adrenal cells in culture, only a few in vivo studies have been conducted on this aspect of development in the primate. For example, Ducsay et al. (1991) showed that ACTH regulated morphologic maturation of the baboon fetal adrenal gland, while Coulter et al. (1996) demonstrated that adrenal growth and IGF-II expression were enhanced in fetal rhesus monkeys in which endogenous ACTH release was increased by the administration of metyrapone.

The baboon provides a valuable model for the study of the endocrinology of human pregnancy and fetal development (Albrecht \& Pepe 1988). In the first phase of the present study, therefore, we used the baboon to determine whether expression of the mRNAs for IGF-II and its principal IGF type-1 receptor and IGF-binding protein-2 (IGFBP-2), as well as bFGF, were developmentally regulated in the primate fetal adrenal gland. In the second phase of this study, fetal pituitary ACTH was suppressed by the administration of betamethasone late in gestation, to determine the possible effect on the mRNA levels for those factors, i.e. IGF-II and IGFBP-2, shown in the first part of the study to be expressed at high levels in the adrenal late in fetal development.

\section{Materials and Methods}

\section{Animals}

Ontogeny Female baboons (Papio anubis), weighing $12-15 \mathrm{~kg}$, were housed individually in large aluminumstainless steel primate cages within a controlled environment $\left(22^{\circ} \mathrm{C}, 12 \mathrm{~h}\right.$ light: $12 \mathrm{~h}$ darkness $)$. Animals were fed twice daily with a commercial primate chow, supplemented daily with fresh fruit and vitamins, and provided water ad libitum. Females were paired with males for 5 days at the time of anticipated ovulation as based upon previous menstrual history and external sex skin turgescence (Albrecht 1980). All animals were cared for and used strictly in accordance with USDA regulations and the NIH Guide for the Care and Use of Laboratory Animals (Publication no. 86-23 1985). The experimental protocol employed in the present study was approved by the Institutional Animal Care and Use Committees of the University of Maryland School of Medicine and Eastern Virginia Medical School.

In the developmental study, fetuses were obtained via Cesarean section on days 60 (early, $n=4), 100$ (mid, $n=6$ ) or 165 (late, $n=7$ ) of gestation (term=184 days) from untreated baboons anesthetized with halothane/nitrous oxide.

Betamethasone treatment Fetuses were also obtained on day 165 from baboons in which fetal pituitary ACTH was suppressed by the administration of betamethasone (Celestone Soluspan, Schering Corp., Chicago, IL, USA) to the fetus $(0.6 \mathrm{mg} / 100 \mu \mathrm{l}$, or approximately $0.79 \mathrm{mg} / \mathrm{kg}$ body weight) only $(n=4)$ or to the fetus $(0 \cdot 6 \mathrm{mg} / 100 \mu \mathrm{l})$ and mother $(6.0 \mathrm{mg} / \mathrm{ml}$, or approximately $0.37 \mathrm{mg} / \mathrm{kg}$ body weight, i.m., $n=4$ ) every other day between days 150 and 164 of gestation. Baboons were sedated with ketamine $\mathrm{HCl}(10 \mathrm{mg} / \mathrm{kg}$ body weight, Ketalar, Aveco Co Inc., Fort Dodge, IA, USA), which prevents the increase in adrenocortical secretion of cortisol typically associated with experimental manipulation and handling of the primate (Albrecht et al. 1978). Animals were then anesthetized with halothane/nitrous oxide and betamethasone administered i.m. to the fetus via a 25 -gauge needle by maternal transabdominal injection. Although betamethasone was administered to both the mother and fetus to ensure that hormonal products of the maternal adrenocortical axis which cross the placenta, such as cortisol and cortisone, would not interfere with the assessment of fetal adrenal function, similar results were obtained with suppression of the fetus alone or both the mother and fetus. However, two of the baboons in which the fetus only received betamethasone delivered spontaneously on days 160 and 164

Fetuses/neonates were killed with an overdose of pentobarbital $(100 \mathrm{mg} / \mathrm{kg}$ body weight; Anpro Pharmaceutical, Arcadia, CA, USA), and the adrenals immediately removed, weighed, and a portion placed into $10 \%$ buffered formalin/PBS fixative for subsequent histology and immunocytochemistry. The remainder of the glands was flash frozen and stored in liquid nitrogen for mRNA analysis.

\section{Isolation of $R N A$}

Total RNA was extracted from fetal adrenals according to the modified method described by Chirgwin et al. (1979). In brief, tissues were homogenized with $4 \mathrm{M}$ guanidine isothiocyanate, the homogenate extracted with chloroform:isoamyl alcohol, and RNA isolated by $5.7 \mathrm{M}$ cesium chloride gradient centrifugation $(174000 \mathrm{~g}$ for $21 \mathrm{~h}$ at $20^{\circ} \mathrm{C}$ ). RNA pellets were solubilized in $0 \cdot 3 \mathrm{M}$ sodium acetate and salt ethanol precipitated overnight at $-20{ }^{\circ} \mathrm{C}$. RNA integrity was assessed by 'minigel' electrophoresis for evaluation of 28 and $18 \mathrm{~S}$ ribosomal RNA and by UV adsorption for concentration and purity. Poly $(\mathrm{A})^{+}$-enriched RNA was prepared by centrifugation of total RNA over pre-equilibrated columns of oligo(dT) cellulose according to the manufacturer's instructions (Pharmacia Biotech, Inc., Piscataway, NJ, USA).

\section{Northern blot analysis}

Fetal adrenal mRNA levels were determined by Northern blot analysis using established methods in our laboratory (Aberdeen et al. 1998). Briefly, $2 \cdot 5 \mu \mathrm{g}$ poly $(\mathrm{A})^{+}$RNA 
were size-fractioned by agarose gel electrophoresis, transferred onto a nylon membrane (GeneScreen, DuPont-New England Nuclear, Boston, MA, USA), UV cross-linked, baked in a vacuum oven $\left(80^{\circ} \mathrm{C}\right.$ for $\left.2 \mathrm{~h}\right)$ and prehybridized $\left(18 \mathrm{~h}\right.$ at $\left.42{ }^{\circ} \mathrm{C}\right)$ in $50 \%$ formamide buffer. Complementary human DNAs for IGF-II (no. 57482), IGF type-1 receptor (no. 59294), and $\beta$-actin (no. 65128) were obtained from American Type Culture Collection (Rockville, MD, USA). Human cDNAs for IGFBP-2 and bFGF were provided by Dr S Shimasaki (University of Southern California, La Jolla, CA, USA) and Dr Judith Abraham (Scios Nova Inc., Mountainview, CA, USA) respectively. Complementary DNAs were labeled with $\left[\alpha-{ }^{32} \mathrm{P}\right]$ deoxy-CTP (Amersham Corp., Arlington Heights, IL, USA) to a specific activity of approximately $10^{9}$ d.p.m./ $\mu \mathrm{g}$ DNA using the Random-Primed DNA Labeling Kit (Boehringer-Mannheim, Indianapolis, IN, USA). RNA containing membranes were hybridized with fresh buffer at $42{ }^{\circ} \mathrm{C}$ for $23 \mathrm{~h}$ with ${ }^{32} \mathrm{P}$-labeled cDNA. Following hybridization, membranes were stringently washed twice at room temperature for $5 \mathrm{~min}$ in $2 \times \mathrm{SSC}$ $(0.03 \mathrm{M} \mathrm{NaCl}, 0.03 \mathrm{M}$ sodium citrate, $\mathrm{pH} \mathrm{7.0)}$ ), once at $65{ }^{\circ} \mathrm{C}$ for $30 \mathrm{~min}$ in $2 \times \mathrm{SSC} / 1 \%$ sodium dodecyl sulfate, and twice in $0 \cdot 1 \times \mathrm{SSC}$ at $22^{\circ} \mathrm{C}$ for $10 \mathrm{~min}$. Membranes were then exposed to Kodak X-AR film (Eastman Kodak, Rochester, NY, USA) at $-80{ }^{\circ} \mathrm{C}$ and autoradiograms developed. The intensities of each autoradiogram were analyzed using a Bio Rad Model 620 video densitometer (Bio Rad, Rockville, MD, USA). Between hybridizations with different probes, membranes were stripped by washing at $100{ }^{\circ} \mathrm{C}$ for $30 \mathrm{~min}$.

\section{Immunocytochemistry and histology}

Sections $(4 \mu \mathrm{m})$ of paraffin-embedded adrenal glands were mounted onto Superfrost microscope slides (Fisher Scientific Co., Arlington, VA, USA), heat fixed and endogenous peroxidase blocked with $0 \cdot 4 \% \quad \mathrm{H}_{2} \mathrm{O}_{2}$ in methanol. After incubation $\left(4^{\circ} \mathrm{C}\right)$ overnight with polyclonal antibody to rabbit anti-human 3 $\beta-\mathrm{HSD}$ (supplied by Dr Ian Mason, University of Edinburgh, Edinburgh, UK) diluted 1:5000 in 5\% normal goat serum (Boehringer-Mannheim), sections were washed and incubated with biotinylated goat anti-mouse or goat anti-rabbit IgG (Boehringer-Mannheim), and stained with Vector-VIP purple substrate (Vector-VIP, Vector Laboratories, Burlingame, CA, USA). Sections of each adrenal were lightly counterstained with methyl green (Vector Laboratories) and mounted in Biomount (Fisher) for analysis of cellular histology.

\section{Statistical analysis}

Densitometric readings (relative arbitrary units) of autoradiograms were corrected for $\beta$-actin and the ratios analyzed using one-way analysis of variance (ANOVA)

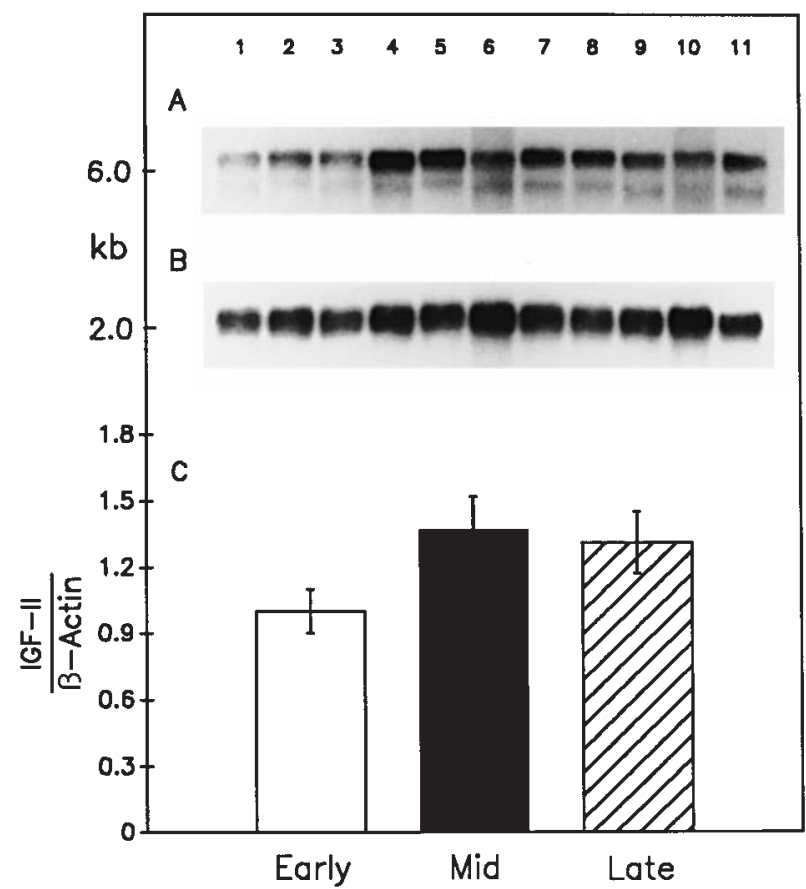

Figure 1 Representative Northern blot of mRNA transcripts for IGF-II (A) and $\beta$-actin (B) in baboon adrenals obtained on days 60 (early, lanes $1-3, n=3$ ), 100 (mid, lanes $4-7, n=4)$ and 165 (late, lanes $8-11, n=4$ ) of gestation (term $=184$ days). Only the primary $6.0 \mathrm{~kb}$ transcript for IGF-II was analyzed by densitometry. (C) Bar graph showing the cumulative densitometric ratios (mean \pm S.E.) of IGF-II/ $\beta$-actin mRNAs for four early, six mid, and seven late gestation fetuses.

and Newman-Keuls multiple comparison test to identify significant differences between individual group means (Instat, Graphpad Software, San Diego, CA, USA).

\section{Results}

\section{Ontogeny}

IGF-II mRNA Two IGF-II mRNA transcripts, a major $6.0 \mathrm{~kb}$ and a minor $4.2 \mathrm{~kb}$ species, were expressed in the baboon fetal adrenal (Fig. 1). The level of expression of the primary $6.0 \mathrm{~kb}$ IGF-II (Fig. 1A) and $\beta$-actin (Fig. 1B) mRNA transcripts, and consequently the ratio of IGFII: $\beta$-actin mRNA levels (Fig. 1C), were similar at early, mid and late gestation.

IGF type-1 receptor mRNA Three mRNA transcripts were observed for the IGF type-1 receptor, a major $12.0 \mathrm{~kb}$ transcript and two minor 9.5 and $7.0 \mathrm{~kb}$ transcripts (Fig. 2A). Expression of the primary $12.0 \mathrm{~kb}$ IGF type-1 receptor transcript in the baboon fetal adrenal followed a unique biphasic pattern. Thus, IGF type-1 receptor $12.0 \mathrm{~kb}$ mRNA levels, expressed as a ratio of $\beta$-actin, were approximately 2 - to 3 -fold greater $(P<0 \cdot 01)$ 


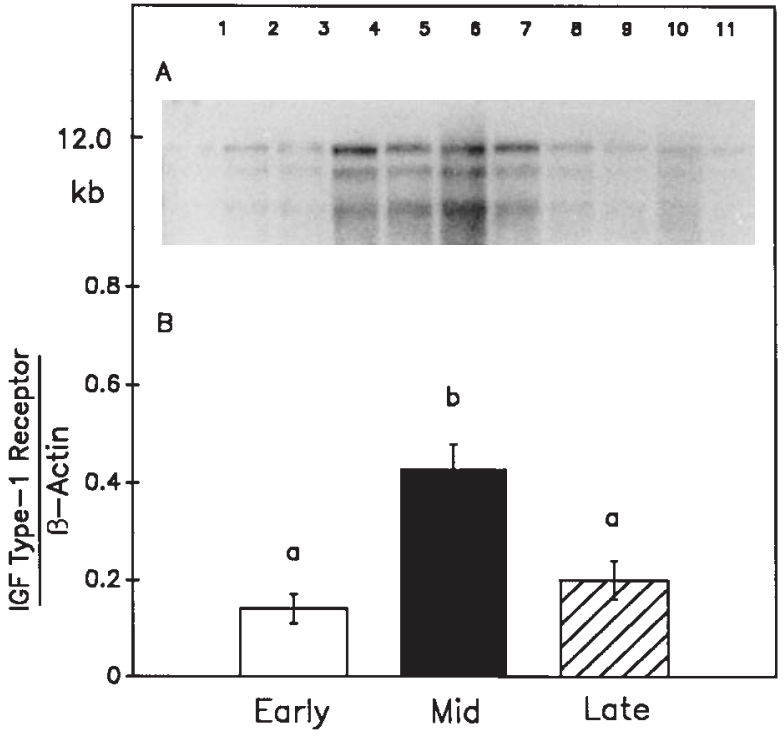

Figure 2 (A) Representative Northern blot of the IGF-type 1 receptor in the fetal adrenals of the three early (lanes $1-3$ ), four mid (lanes 4-7), and four late (lanes 8-11) gestation baboon fetuses shown in Fig. 1A. (B) Densitometric ratios (mean \pm S.E.) of the $12.0 \mathrm{~kb}$ IGF-type 1 receptor/ $\beta$-actin mRNA transcripts in baboon fetal adrenals of the animals shown in Fig. 1C. Group means with different letter superscripts differ from each other at $P<0 \cdot 01$ (ANOVA and Newman-Keuls multiple comparison test).

at mid $(0.43 \pm 0.05$ arbitrary units, mean \pm S.E. $)$ than at early $(0.14 \pm 0.03)$ or late $(0.20 \pm 0.04)$ gestation (Fig. 2B).

IGFBP-2 mRNA The baboon fetal adrenal expressed a single $1.5 \mathrm{~kb}$ mRNA transcript for IGFBP-2. IGFBP-2 mRNA expression (Fig. 3A) was similar at early $(0.96 \pm 0.09$, mean \pm s.E. $)$ and mid $(0.79 \pm 0.12)$ gestation (Fig. 3B), and increased at late gestation to a value $(1 \cdot 95 \pm 0 \cdot 11)$ that was approximately 2 -fold greater $(P<0 \cdot 001)$ than earlier in pregnancy.

bFGF mRNA There was an increase in expression of the single $7.8 \mathrm{~kb}$ mRNA transcript for bFGF in the baboon fetal adrenal in late gestation. Thus, bFGF mRNA levels expressed as a ratio of $\beta$-actin (Fig. 4B) were approximately 5 - and 2 -fold greater $(P<0 \cdot 05)$ at late $(1 \cdot 12 \pm 0 \cdot 22$, mean \pm S.E. $)$ than at early $(0 \cdot 21 \pm 0 \cdot 01)$ and mid $(0 \cdot 40 \pm 0 \cdot 03)$ gestation respectively.

\section{Effect of betamethasone}

Fetal adrenal and body weights Fetal adrenal and body weights increased progressively $(P<0 \cdot 01)$ between days 60,100 and 165 of gestation (Table 1). We have previously shown (Leavitt et al. 1997) that fetal pituitary pro-opiomelanocortin (POMC) mRNA levels were 45\%

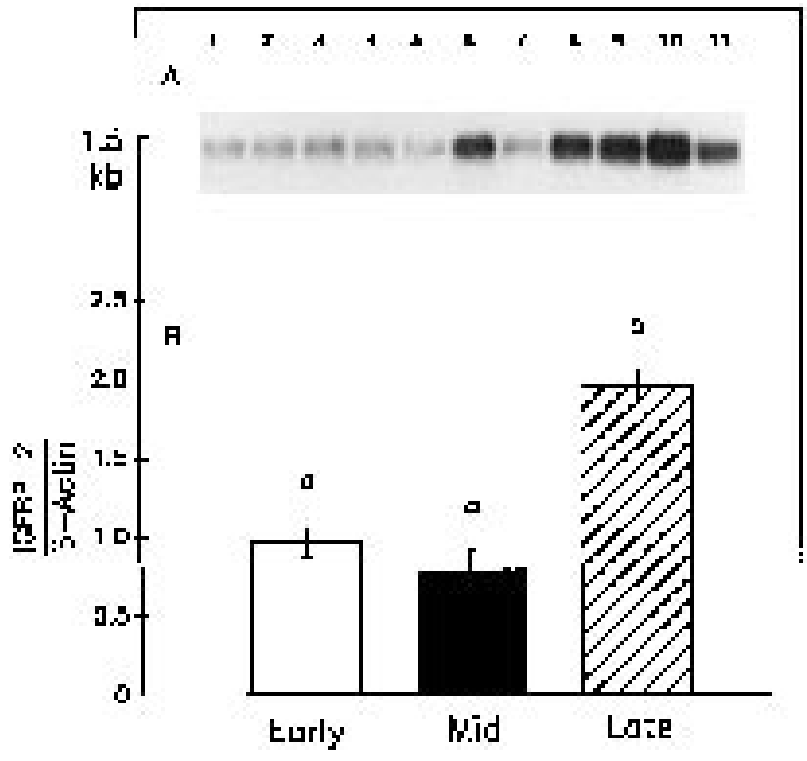

Figure 3 (A) Representative Northern blot of IGFBP-2 in the baboon fetal adrenal of the three early (lanes 1-3), four mid (lanes 4-7) and four late (lanes 8-11) gestation animals shown in Fig. 1A. (B) Densitometric ratios (mean \pm S.E.) of the $1.5 \mathrm{~kb}$ IGFBP-2 and $\beta$-actin mRNA transcripts for the animals shown in Fig. 1C. Group means with different letter superscripts differ from each other at $P<0 \cdot 001$.

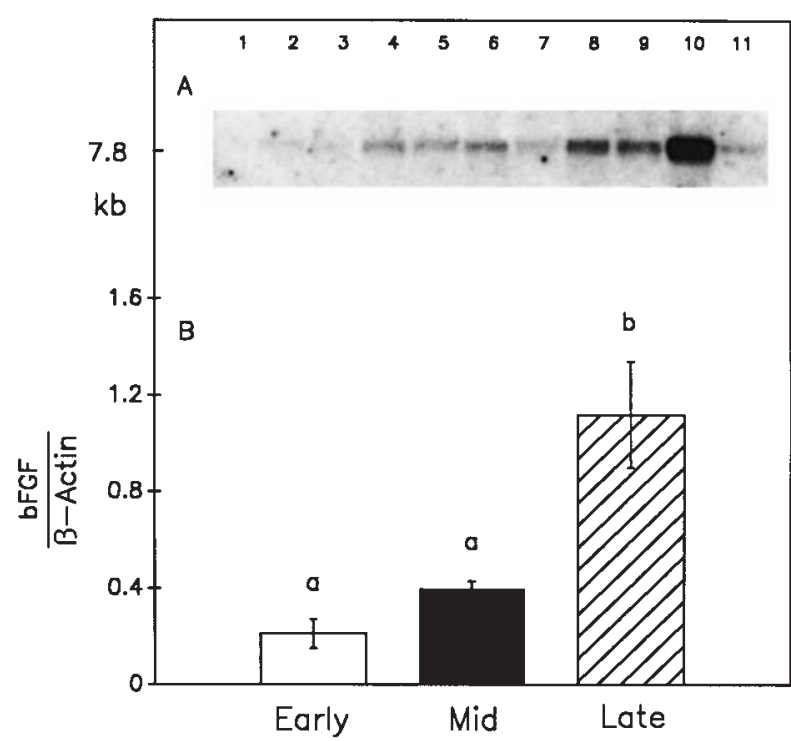

Figure 4 (A) Representative Northern blot of bFGF in the baboon fetal adrenal of the three early (lanes 1-3), four mid (lanes 4-7), and four late (lanes 8-11) gestation animals shown in Fig. 1A. (B) Densitometric ratios (mean \pm S.E.) of the $7.8 \mathrm{~kb} \mathrm{bFGF}$ and $\beta$-actin mRNA transcripts for the autoradiogram shown in panel A. Group means with different letter superscripts differ from each other at $P<0.05$. 
Table 1 Fetal adrenal and fetal and maternal body weights in untreated and betamethasone-treated baboons. *Betamethasone was injected i.m. into the fetus $(0.6 \mathrm{mg})$ or the mother $(6 \mathrm{mg})$ and fetus $(0.6 \mathrm{mg})$ every other day between days 150 and 164 of gestation (term $=184$ days). Values (means \pm S.E.) indicated by different letter superscripts differ from each other at $P<0 \cdot 01$ (ANOVA)

\begin{tabular}{|c|c|c|c|c|}
\hline & $N$ & $\begin{array}{l}\text { Adrenal } \\
\text { (mg/two glands) }\end{array}$ & $\begin{array}{l}\text { Fetal body weight } \\
\text { (g) }\end{array}$ & $\begin{array}{l}\text { Maternal body } \\
\text { weight }(\mathrm{kg})\end{array}$ \\
\hline \multicolumn{5}{|l|}{ Group } \\
\hline Early (day 60) & 4 & $64 \pm 7^{\mathrm{a}}$ & $9 \pm 1^{\mathrm{a}}$ & $20 \cdot 1 \pm 2 \cdot 8$ \\
\hline Mid (day 100) & 6 & $134 \pm 10^{b}$ & $174 \pm 7^{b}$ & $16 \cdot 8 \pm 0 \cdot 9$ \\
\hline Late (day 165) & 7 & $345 \pm 25^{c}$ & $794 \pm 68^{c}$ & $17 \cdot 2 \pm 0 \cdot 7$ \\
\hline $\begin{array}{l}\text { Late + betamethasone* } \\
\text { (day 165) }\end{array}$ & 8 & $183 \pm 20^{d}$ & $754 \pm 88^{\mathrm{c}}$ & $16 \cdot 4 \pm 0 \cdot 9$ \\
\hline
\end{tabular}

lower in betamethasone-treated baboons. As shown in Table 1, this resulted in a comparable decrease $(P<0 \cdot 01)$ in adrenal weights of fetuses delivered by Cesarean section or spontaneously. In contrast, fetal and maternal body weights on day 165 were not altered by betamethasone administration.

\section{Adrenal 3ß-HSD immunocytochemistry and histol-} ogy A relatively wide band of immunocytochemical staining for $3 \beta-H S D$, an enzyme expressed specifically within the definitive and transitional zones of the cortex (Doody et al. 1990, Coulter et al. 1996), was evident in the fetal adrenal of untreated baboons late in gestation (Fig. 5A). The width of this band of $3 \beta-H S D$ immunostaining was greatly diminished in the fetal adrenals of all of the baboons treated with betamethasone, whether delivered by Cesarean section or spontaneously (Fig. 5B). However, cellular integrity of the fetal adrenal cortex was not compromised as shown histologically (Fig. 5) and by the maintenance of $\beta$-actin mRNA expression (Fig. 6).

IGF-II mRNA Adrenal IGF-II mRNA expression was not decreased by the administration of betamethasone to neonates that were either obtained by Cesarean section, or by spontaneous vaginal delivery, when compared with the untreated controls (Fig. 6). Thus, IGF-II mRNA levels, expressed as a ratio of $\beta$-actin, were similar in the untreated controls $(0 \cdot 83 \pm 0 \cdot 08$, mean \pm s.E. $)$ and in the betamethasone-treated baboons delivered by Cesarean section $(0 \cdot 89 \pm 0 \cdot 31)$ or spontaneously (0.83, Fig. $6 \mathrm{C})$.

IGFBP-2 mRNA Fetal adrenal IGFBP-2 mRNA levels were similar in untreated controls $(0 \cdot 68 \pm 0 \cdot 07$, mean \pm S.E.) and in neonates delivered spontaneously to betamethasone-treated animals (0.96, Fig. 7). However, IGFBP-2 mRNA expression appeared greater $(P<0 \cdot 01)$ in betamethasone-treated animals delivered by Cesarean section $(2 \cdot 48 \pm 0 \cdot 44)$.

\section{Discussion}

The present study shows that there were three different patterns of developmental expression of IGF-II, the IGF type-1 receptor, and IGFBP-2/bFGF mRNA levels in the baboon fetal adrenal gland. IGF-II mRNA expression was
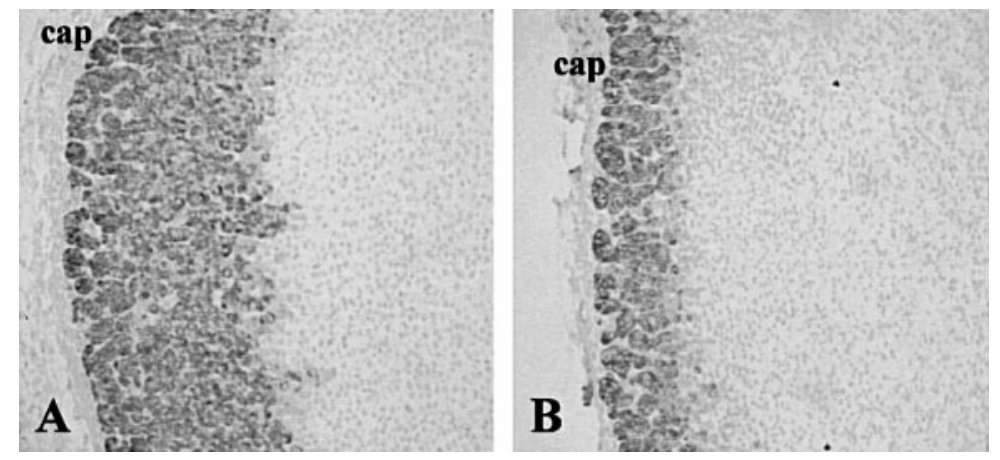

Figure 5 Representative photomicrographs of adrenal 3 $\beta$-HSD immunocytochemistry in fetuses obtained on day 165 of gestation from untreated control (A) and betamethasone-treated (B) baboons. See footnote of Table 1 for details of betamethasone treatment. Magnification is approximately $100 \times$. cap, capsularis. 


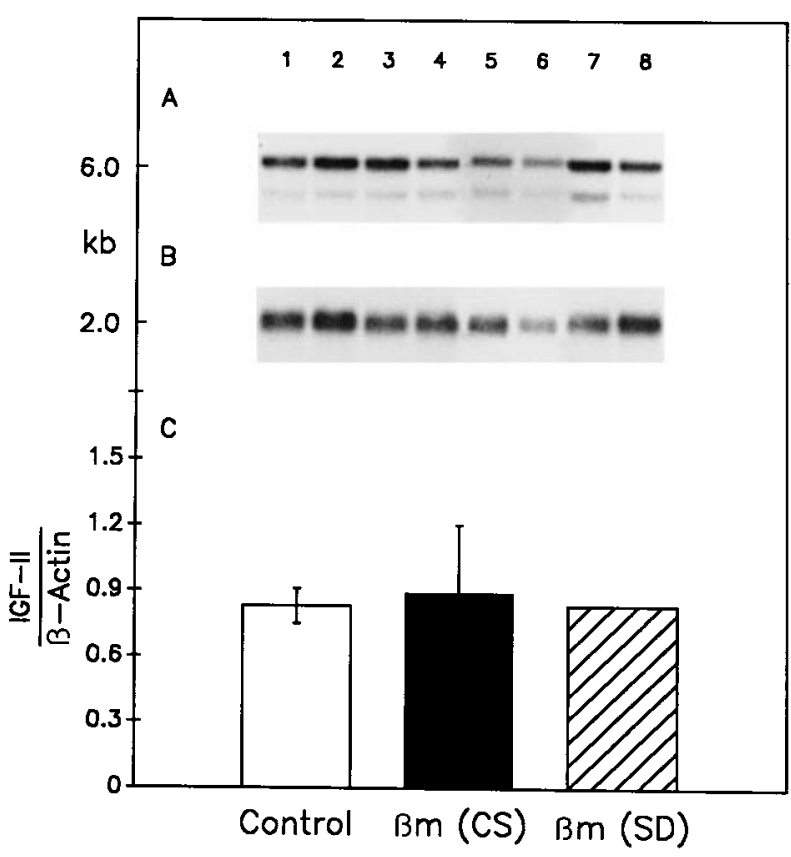

Figure 6 Northern blot of the mRNA for IGF-II (A) and $\beta$-actin (B) in fetal adrenal glands obtained on day 165 of gestation from untreated control baboons $(n=3$, lanes $1-3)$ and from baboons administered betamethasone $(\beta \mathrm{m})$ between days 150 and 164 of gestation and delivered by Cesarean section (CS, $n=3$, lanes 5-7) or spontaneously (SD, $n=2$, lanes 4 and 8). (C) Mean ( \pm S.E.) mRNA ratios of the $6.0 \mathrm{~kb}$ IGF-II and $\beta$-actin mRNA transcripts for the animals shown in panel $A$.

unchanged at early, mid and late gestation. These results are consistent with those of Coulter et al. (1996), who demonstrated that the abundance of immunocytochemically demonstrable IGF-II protein was similar at mid and late gestation in the rhesus monkey fetal adrenal gland. Using in situ hybridization, it has also been demonstrated that IGF-II mRNA was distributed throughout the cortex of the developing human (Mesiano et al. 1993), monkey (Coulter et al. 1996) and baboon (G W Aberdeen, G J Pepe \& ED Albrecht, unpublished observation) fetal adrenal gland. Because only mRNA levels were determined in the fetal adrenals of baboons of the present study, however, the potential functional significance of the current results for mRNA expression will depend on future quantification and immunocytochemical localization of the proteins for the respective peptide growth factors. However, if the developmental patterns for the levels and cellular localization of the proteins for these growth factors parallel mRNA expression, then the sustained expression of IGF-II within the fetal adrenal presumably would provide a mechanism for promoting cellular proliferation of this important endocrine gland throughout human and nonhuman primate gestation.

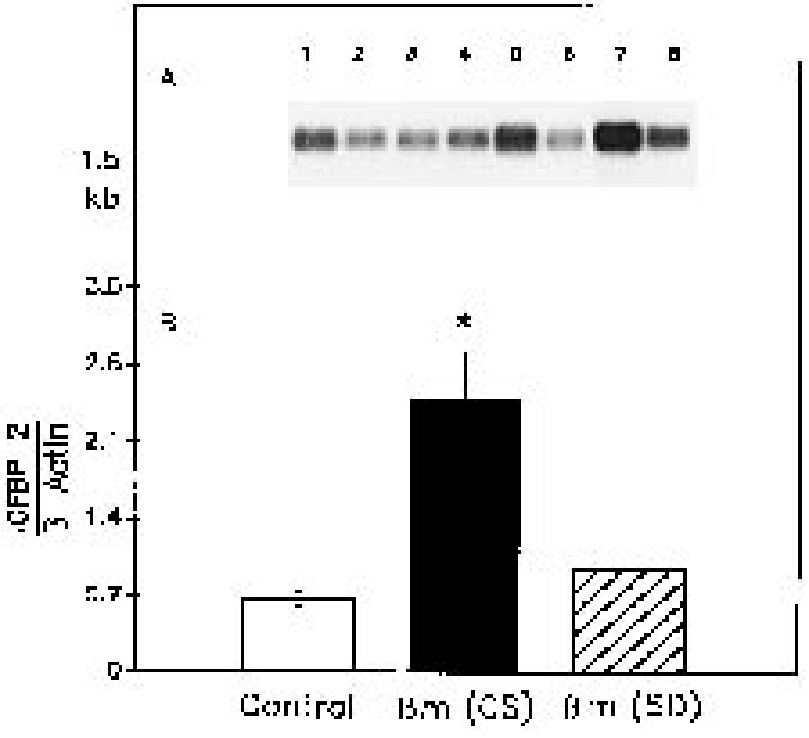

Figure 7 (A) Northern blot of fetal adrenal IGFBP-2 mRNA expression of the baboons shown in Fig. 6. (B) Mean ( \pm S.E.) mRNA ratios of the $1.5 \mathrm{~kb}$ IGFBP- 2 and $\beta$-actin mRNA transcripts for animals shown in panel $A$. ${ }^{*}$ Greater $(P<0 \cdot 01)$ than value of untreated control.

In contrast to the expression of IGF-II, the mRNA for the IGF type-1 receptor exhibited a biphasic pattern of expression, which appeared similar to that we have previously shown for ACTH receptor mRNA levels in the baboon fetal adrenal gland (Albrecht et al. 1996). The upregulation of IGF receptor between early and midgestation must occur within the fetal zone, which makes up almost the entire cortex at this time in gestation, presumably to provide a mechanism for mediating the action of IGF-II upon fetal zone development. The marked decrease in IGF type-1 receptor expression in the second half of baboon gestation is consistent with the decline in the mRNA for this receptor determined by in situ hybridization in the rhesus monkey fetal adrenal between mid and late gestation (Coulter et al. 1996). Although the IGF type-1 receptor appeared to be expressed throughout the rhesus monkey fetal adrenal cortex (Coulter et al. 1996), the decline in expression observed in baboons of the present study may also occur within the fetal zone, which we have previously shown exhibits a functional decline with respect to DHA secretion (Walker et al. 1987, 1988, Berghorn et al. 1995) and ACTH receptor mRNA expression (Aberdeen et al. 1997) in the second half of pregnancy. The IGF receptor mRNA remaining, albeit in low levels, may be present within the transitional zone which emerges in late gestation, providing a mechanism to mediate the action of IGF-II upon proliferation and maturation of this cortical zone in preparation for the production of cortisol. In situ hybridization and/or immunocytochemical localization 
studies as well as quantification of respective protein, however, will be required to definitively determine the latter possibilities.

In contrast to the patterns of IGF-II and IGF type-1 receptor expression, the mRNAs for the major IGFBP, IGFBP-2, and bFGF increased in the fetal adrenal gland in late baboon pregnancy. This developmental pattern of IGFBP-2 and bFGF mRNA expression is similar to that previously shown for 3 $\beta-H S D$ (Albrecht et al. 1996, Aberdeen et al. 1997), the expression of which is confined to the emerging transitional and definitive zones (Doody et al. 1990, Mesiano et al. 1993). Although IGFBP-2 was expressed throughout the fetal adrenal cortex of the rhesus monkey (Coulter et al. 1996), it is possible that IGFBP-2 and/or bFGF, like $3 \beta-\mathrm{HSD}$, become expressed in greater abundance in the transitional zone of the baboon fetal adrenal very late in gestation. If confirmed by in situ hybridization and if increased mRNA were translated into more growth factor protein, the latter would potentially provide a means of promoting growth and differentiation of the transitional zone for cortisol biosynthesis late in gestation. Indeed, bFGF has been described as one of the most potent mitogens for human fetal adrenocortical cells (Hornsby \& Gill 1977, Crickard et al. 1981, Jaffe et al. 1981). In addition, bFGF is an important angiogenic factor (Basilico \& Moscatelli 1992, Bikfalvi et al. 1997) and may therefore also have a role in neovascularization of the developing fetal adrenal gland.

The results of the present study also show that despite a decline in fetal pituitary POMC mRNA/ACTH peptide expression (Leavitt et al. 1997) and adrenal weight after betamethasone administration, adrenal IGF-II and IGFBP-2 mRNA levels were not decreased in baboon neonates delivered either spontaneously or by Cesarean section. The maintenance of IGF-II and IGFBP-2 mRNA expression differs from the striking suppression we recently reported in expression of the ACTH receptor, as well as the $3 \beta-H S D, P 450$ cholesterol side-chain cleavage and $\mathrm{P} 45017 \alpha$-hydroxylase- $\mathrm{C}_{17,20}$ lyase steroidogenic enzymes, in the fetal adrenal of these same Cesareansectioned baboons after betamethasone suppression of ACTH (Leavitt et al. 1997). The maintenance of IGF-II mRNA levels throughout gestation, and the lack of effect of betamethasone, suggest that under the experimental conditions employed in this study the expression of the mRNA for this peptide growth factor in contrast to the steroidogenic enzymes in the baboon fetal adrenal gland is not dependent upon pituitary ACTH. This does not mean, however, that basal levels of IGF-II cannot be stimulated by elevations in ACTH, because ACTH clearly upregulates fetal adrenal IGF-II both in vitro (Voutilainen \& Miller 1987, Ilvesmaki et al. 1993b, Mesiano et al. 1993) and in vivo (Coulter et al. 1996). This would imply that there are at least two components to IGF-II expression in the primate fetal adrenal gland, although further investigation is needed to determine the specific nature of this regulation. The underlying cause of the elevation in fetal adrenal IGFBP-2 mRNA levels in betamethasonetreated fetuses delivered by Cesarean section is unknown, particularly since ACTH levels probably became elevated with spontaneous but not with Cesarean delivery.

Natural glucocorticoids have the capacity to act directly upon rat adrenal cells in culture to suppress ACTHinduced steroidogenesis (Carsia et al. 1983). Moreover, cortisol downregulates IGF-II gene expression in the sheep fetal adrenal late in gestation (Lu et al. 1994, Li et al. 1998). Therefore, the potential direct action of glucocorticoids on the adrenal must be considered when using betamethasone to study in vivo the role of ACTH on adrenocortical function. Nevertheless, because IGF-II and IGFBP-2 mRNA levels were maintained, whereas ACTH receptor and $\mathrm{P} 450$ steroidogenic enzyme expression was decreased in the adrenal of baboon fetuses in which pituitary POMC/ACTH expression was inhibited by betamethasone, we suggest that there is a difference in responsivity of the peptide growth factor system and the steroidogenic pathway to ACTH in the developing baboon fetal adrenal gland.

In summary, very different patterns of mRNA levels for IGF-II, IGF type-1 receptor, IGFBP-2, and bFGF were exhibited in the developing baboon fetal adrenal gland. This differential pattern of peptide growth factor expression may reflect functionally important differences in their respective cellular localization within the cortex, as well as a divergence in the functional development of the fetal, transitional and definitive zones of the baboon fetal adrenal cortex.

\section{Acknowledgements}

This work was supported by NIH Research Grant RO1 HD-13294. The authors wish to thank Mrs Wanda H James for secretarial assistance with this manuscript.

\section{References}

Aberdeen GW, Babischkin JS, Davies WA, Pepe GJ \& Albrecht ED 1997 Decline in adrenocorticotropin receptor messenger ribonucleic acid expression in the baboon fetal adrenocortical zone in the second half of pregnancy. Endocrinology 138 1634-1641.

Aberdeen GW, Leavitt MG, Pepe GJ \& Albrecht ED 1998 Effect of maternal betamethasone administration at midgestation on baboon fetal adrenal gland development and ACTH receptor messenger RNA expression. Journal of Clinical Endocrinology and Metabolism $\mathbf{8 3}$ 976-982.

Albrecht ED 1980 A role of estrogen in progesterone production during baboon pregnancy. American Journal of Obstetrics and Gynecology 136 569-574.

Albrecht ED \& Pepe GJ 1988 Endocrinology of Pregnancy. In Nonhuman Primates in Perinatal Research, pp 13-23. Eds YW Brans \& TJ Kuehl. New York: John Wiley \& Sons, Inc.

Albrecht ED \& Pepe GJ 1990 Placental steroid hormone biosynthesis in primate pregnancy. Endocrine Reviews 11 124-150. 
Albrecht ED, Nightingale MS \& Townsley JD 1978 Stress-induced decreases in the serum concentration of progesterone in the pregnant baboon. Journal of Endocrinology 77 425-426.

Albrecht ED, Aberdeen GW, Babischkin JS, Tilly JL \& Pepe GJ 1996 Biphasic developmental expression of adrenocorticotropin receptor messenger ribonucleic acid levels in the baboon fetal adrenal gland. Endocrinology 137 1291-1298.

Ballard PL \& Ballard RA 1972 Glucocorticoid receptors and the role of glucocorticoids in fetal lung development. Proceedings of the National Academy of Sciences of the USA 69 2668-2672.

Basilico C \& Moscatelli P 1992 The FGF family of growth factors and oncogenes. Advanced Cancer Research 59 115-165.

Berghorn KA, Albrecht ED \& Pepe GJ 1995 Activation of baboon fetal pituitary-adrenocortical axis at midgestation by estrogen: responsivity of the fetal adrenal to ACTH in vitro. Biology of Reproduction 53 996-1002.

Bikfalvi A, Klein S, Pintucci G \& Rifkin DB 1997 Biological roles of fibroblast growth factor-2. Endocrine Reviews 18 26-45.

Carsia RV, MacDonald GJ \& Malamed S 1983 Steroid control of steroidogenesis in isolated adrenocortical cells: molecular and species specificity. Steroids 41 741-755.

Chirgwin JM, Przybyla AE, MacDonald RJ \& Rutter WJ 1979 Isolation of biologically active ribonucleic acid from sources enriched in ribonuclease. Biochemistry 18 5294-5299.

Coulter CL, Goldsmith PC, Mesiano S, Voytek CC, Martin MC, Han VKM \& Jaffe RB 1996 Functional maturation of the primate fetal adrenal in vivo: I. role of insulin-like growth factors (IGFs), IGF-I receptor, and IGF binding proteins in growth regulation. Endocrinology 137 4487-4498.

Crickard K, Ill CR \& Jaffe RB 1981 Control of proliferation of human fetal adrenal cells in vitro. Journal of Clinical Endocrinology and Metabolism 53 790-796

DiBlasio AM, Fujii DK, Yamamoto M, Martin MC \& Jaffe RB 1990 Maintenance of cell proliferation and steroidogenesis in cultured human fetal adrenal cells chronically exposed to adrenocorticotropic hormone: rationalization of in vitro and in vivo findings. Biology of Reproduction 42 683-691.

Doody KM, Carr BR, Rainey WE, Byrd W, Murry BA, Strickler RC, Thomas JL \& Mason JI 1990 3ß-Hydroxysteroid dehydrogenase/ isomerase in the fetal zone and neocortex of the human fetal adrenal gland. Endocrinology 126 2487-2492.

Ducsay CA, Hess HL, McClellan MC \& Novy MJ 1991 Endocrine and morphological maturation of the fetal and neonatal adrenal cortex in baboons. Journal of Clinical Endocrinology and Metabolism 73 385-395.

Guide for the Care and Use of Laboratory Animals, HHS, NIH Publication No. 86-23 1985.

Han VKM, D'Ercole AJ \& Lund PK 1987 Cellular localization of somatomedin (insulin-like growth factor) messenger RNA in the human fetus. Science 236 193-198.

Han VKM, Lund PK, Lee DC \& D'Ercole AJ 1988 Expression of somatomedin/insulin-like growth factor messenger ribonucleic acids in the human fetus: identification, characterization and tissue distribution. Journal of Clinical Endocrinology and Metabolism 66 422-429.

Han VKM, Lu F, Bassett N, Yang KKP, Delhanty PJD \& Challis JRG 1992 Insulin-like growth factor-II (IGF-II) messenger ribonucleic acid is expressed in steroidogenic cells of the developing ovine adrenal gland: evidence of an autocrine/paracrine role for IGF-II. Endocrinology 131 3100-3109.

Hornsby PJ \& Gill GN 1977 Hormonal control of adrenocortical cell proliferation: desensitization to $\mathrm{ACTH}$, and interaction of $\mathrm{ACTH}$ and fibroblast growth factor in bovine adrenocortical cell cultures. Journal of Clinical Investigation 60 342-352.
Ilvesmaki V, Blum WF \& Voutilainen R 1993a Insulin-like growth factor binding proteins in the human adrenal gland. Molecular and Cellular Endocrinology 97 71-79.

Ilvesmaki V, Blum WF \& Voutilainen R 1993 b Insulin-like growth factor-II in human fetal adrenals: regulation by ACTH, protein kinase C and growth factors. Journal of Endocrinology 137 533-542.

Jaffe RB, Seron-Ferre M, Crickard K, Koritnik D, Mitchell BF \& Huhtaniemi IT 1981 Regulation and function of the primate fetal adrenal gland and gonad. Recent Progress in Hormone Research 37 41-103.

Leavitt MG, Aberdeen GW, Burch MG, Albrecht ED \& Pepe GJ 1997 Inhibition of fetal adrenal adrenocorticotropin receptor messenger ribonucleic acid expression by betamethasone administration to the baboon fetus in late gestation. Endocrinology 138 2705-2712.

Li J, Saunders JC, Fowden AL, Dauncey MJ \& Gilmour RS 1998 Transcriptional regulation of insulin-like growth factor-II gene expression by cortisol in fetal sheep during late gestation. Journal of Biological Chemistry 273 1058-10593.

Lu F, Han VKM, Milne WK, Fraser M, Carter AM, Berdusco ETM \& Challis JRG 1994 Regulation of insulin-like growth factor-II gene expression in the ovine fetal adrenal gland by adrenocorticotropic hormone and cortisol. Endocrinology 134 2628-2635.

Mesiano S \& Jaffe RB 1997 Developmental and functional biology of the primate fetal adrenal cortex. Endocrine Reviews 18 378403.

Mesiano S, Mellon SH, Gospodarowicz D, DiBlasio AM \& Jaffe RB 1991 Basic fibroblast growth factor expression is regulated by corticotropin in the human fetal adrenal: a model for adrenal growth regulation. Proceedings of the National Academy of Sciences of the USA 88 5428-5432.

Mesiano S, Mellon SH \& Jaffe RB 1993 Mitogenic action, regulation, and localization of insulin-like growth factors in the human fetal adrenal gland. Journal of Clinical Endocrinology and Metabolism 76 968-976.

Pepe GJ \& Albrecht ED 1990 Regulation of the primate fetal adrenal cortex. Endocrine Reviews 11 151-176.

Roos BA 1974 Effect of ACTH and cAMP on human adrenocortical growth and function in vitro. Endocrinology 94 685-690.

Simonian MH \& Gill GN 1981 Regulation of the fetal human adrenal cortex: effects of adrenocorticotropin on growth and function of monolayer cultures of fetal and definitive zone cells. Endocrinology 108 1769-1779.

Voutilainen R \& Miller WL 1987 Coordinate tropic hormone regulation of mRNAs for insulin-like growth factor II and the cholesterol side-chain-cleavage enzyme, $\mathrm{P} 450 \mathrm{scc}$, in human steroidogenic tissues. Proceedings of the National Academy of Sciences of the USA 81 1590-1596.

Voutilainen R \& Miller WL 1988 Developmental and hormonal regulation of mRNAs for insulin-like growth factor II and steroidogenic enzymes in human fetal adrenals and gonads. DNA 7 9-15.

Walker ML, Pepe GJ \& Albrecht ED 1987 Changes in the pattern of androgen formation in vitro by the baboon fetal adrenal gland at mid and late gestation. Biology of Reproduction 37 1192-1197.

Walker ML, Pepe GJ \& Albrecht ED 1988 Regulation of baboon fetal adrenal androgen formation by pituitary peptides at mid and late gestation. Endocrinology 122 546-551.

Received 18 December 1998

Revised manuscript received 20 April 1999

Accepted 12 May 1999 